\title{
Combination of Ultrasound-Guided Percutaneous Microwave Ablation and Radioiodine Therapy in Benign Thyroid Disease: A 3-Month Follow-Up Study
}

\section{Kombination von ultraschallgesteuerter perkutaner Mikrowellen- ablation mit Radiojodtherapie zur Behandlung benigner Schilddrüsen- krankheiten - Eine 3-monatige Kontrollstudie}

Authors

Affiliation

\author{
H. Korkusuz, C. Happel, D. A. Koch, F. Gruenwald
}

Department of Nuclear Medicine, Johann Wolfgang Goethe University Hospital, Frankfurt, Germany

\author{
Key words \\ - combined therapy \\ - radioiodine \\ - microwave ablation \\ - thyroid function \\ nodular goiter
}

received 2.3.2015

accepted $\quad 8.8 .2015$

\section{Bibliography}

DOI http://dx.doi.org/ 10.1055/s-0041-106538

Published online: 13.11.2015

Fortschr Röntgenstr 2016; 188: 60-68 @ Georg Thieme Verlag KG Stuttgart · New York . ISSN 1438-9029

\section{Correspondence}

Dr. Huedayi Korkusuz Department of Nuclear Medicine, Johann Wolfgang Goethe University Hospital Theodor-Stern-Kai 7 60590 Frankfurt Germany

Tel.: ++49/69/63 01-6783 Fax: ++49/69/63 01-7143 huedayi.korkusuz@kgu.de

\section{Zusammenfassung \\ V}

Ziel: Erste Studien zu verschiedenen Kombinationstherapien zur Behandlung benigner nodulärer Strumen überzeugten mit vielversprechenden Ergebnissen. Ziel der Studie war die Effektivität der kombinierten Mikrowellenablation (MWA) und Radiojodtherapie (RIT) zu prüfen, wobei die Schilddrüsenfunktion nach 3 Monaten im Fokus stand.

Material und Methoden: Fünfzehn Patienten (medianes Alter 55 Jahre) mit großen Strumen und Morbus Basedow oder benignen Schilddrüsenknoten erhielten die Kombinationstherapie. Im Serum wurden Triiodthyronin (T3), Thyroxin (T4), Thyreotropin (TSH), Thyreoglobulin (Tg) und Antikörper gegen Thyreoglobulin- (TgAK), Thyreotropin-Rezeptoren (TRAK) und Thyreoperoxidase (TPO-AK) bei der Voruntersuchung, post-MWA und bei der 3-monatigen Kontrolle (3MKU) untersucht. Um die Effektivität zu ermitteln, wurden zusätzlich Schilddrüsenvolumen, benötigte I-131-Therapieaktivität und Krankenhausliegedauer analysiert. Für die unter Lokalanästhesie durchgeführte MWA wurde ein System im Wellenlängenbereich von 902 bis $928 \mathrm{MHz}$ eingesetzt.

Ergebnisse: TSH, T4, T3 und Tg veränderten sich bei der 3MKU gegenüber den Initialwerten nicht; die Patienten blieben euthyreot, außer zwei Patienten, wo eine Verbesserung der initialen TSHWerte in den Normbereich beobachtet werden konnte. Ein Patient entwickelte einen hohen TRAK-Wert, der sich jedoch wieder normalisierte. Die 3MKU ergab eine mittlere Volumenreduktion der SD um $26,4 \mathrm{ml} \pm 7,9 \mathrm{ml}(30,5 \% \pm 4,6 \%$ $(p<0,05))$. Die benötigte Therapieaktivität konnte um $26,6 \% \pm 4,8 \%(\mathrm{p}<0,05)$ und die Krankenhausliegedauer um $30,9 \% \pm 19,9 \%(p<0,05)$ gesenkt werden.

Schlussfolgerung: Die erhobenen Daten bestätigen die Effektivität der Kombination von MWA mit RIT. Die Kombinationstherapie ist ein innova-

\section{Abstract \\ $\nabla$}

Purpose: Pilot studies of combined therapies treating benign nodular goiters reported promising results. The aim of this study was to investigate the effectiveness of combined microwave ablation (MWA) and radioiodine therapy (RIT) with a special focus on thyroid function at the 3-month follow-up.

Materials and Methods: 15 patients (median age: 55 years) with a large goiter and benign thyroid nodules or Graves' disease were treated with the combined therapy. Serum levels of triiodothyronine (T3), thyroxine (T4), thyrotropin (TSH), thyroglobuline ( $\mathrm{Tg}$ ) and, additionally, antibody levels against thyroglobulin (TgAb), thyrotropin receptors (TRAb) and thyroid peroxidase (TPOAb) were measured at enrollment, post MWA and at the 3month follow-up (3MFU). Furthermore, the goiter volume, I-131 dose and hospitalization time were analyzed to evaluate effectiveness. MWA was operated under local anesthesia with a system working in a wavelength field of 902 to $928 \mathrm{MHz}$.

Results: TSH, T4, T3 and Tg did not change at 3MFU, except for in two patients in whom the initial TSH levels improved to normal thyroid functioning levels at follow-up. One of the patients developed a high TRAb-level that receded back into the normal range. At 3MFU, the combined therapy showed a mean thyroid volume reduction of $26.4 \mathrm{ml} \pm 7.9 \mathrm{ml}$ $(30.5 \% \pm 4.6 \%(\mathrm{p}<0.05))$. By utilizing the combined therapy, administered activity could be reduced by $26.6 \% \pm 4.8 \%(\mathrm{p}<0.05)$ and hospitalization time by $30.9 \% \pm 19.9 \%(\mathrm{p}<0.05)$.

Conclusion: The data confirmed the effectiveness of the combination of MWA with RIT. The combined therapy is an innovative and conservative approach and could become a safe alternative to surgery for the treatment of very large benign nodular goiters. Due to the short follow-up and the limited number of patients, further studies will be necessary. 
tiver und effektiver Ansatz und könnte in Zukunft als eine sichere Alternative zur operativen Entfernung großer benigner nodulärer Strumen gesehen werden. Aufgrund des kurzen Follow-ups und der geringen Patientenzahl müssen weitere Studien die Ergebnisse bestätigen.

Kernaussagen:

- die Kombinationstherapie weist eine signifikante Volumenreduktion bei großen benignen nodulären Strumen auf

- die initiale MWA ermöglicht durch eine Reduktion der benötigten Therapieaktivität eine effizientere RIT

- die Schilddrüsenfunktion bleibt bei der kombinierten Therapie erhalten
Key Points:

- The combined therapy shows a significant volume reduction in benign nodular goiters

- Initial MWA improves the RIT results by reducing the required therapy activity

- Thyroid function is preserved after combined therapy

Citation Format:

- Korkusuz H, Happel C, Koch DA. etal. Combination of Ultrasound-Guided Percutaneous Microwave Ablation and Radioiodine Therapy in Benign Thyroid Disease: A 3-Month Follow-Up Study. Fortschr Röntgenstr 2016; 188: 60-68

\section{Introduction}

$\nabla$

A frequently encountered problem regarding the thyroid gland is growing goiters. Goiters with growing benign nodules cause problems and thus require treatment. Common problems are cosmetic issues, local pain, subjective symptoms, caused by compression of the trachea or esophagus, and systematic symptoms of hyperthyroidism or anxiety about malignant change [1]. Conventional treatments of nodular goiters include thyroidectomy and radioiodine therapy. The surgical approach is frequently preferred for patients with nodules larger than $5 \mathrm{~cm}[2,3]$. The reason is that in large nodules with more volume, I-31 therapy is less effective and side effects are more frequent due to the higher doses required for larger volumes $[4,5]$. Although surgery remains the standard of care, nonsurgical treatment may be an acceptable option. New image-guided minimally invasive approaches such as radiofrequency therapy (RFT), laser ablation therapy (LAT), percutaneous ethanol injection therapy (PEIT) and high intensity focused ultrasound (HIFU) offer an effective, safe and less expensive alternative to surgery for treating symptomatic or enlarging nodules [6-8]. Thermal ablation with microwaves (MWA) represents a fairly new therapy for thyroid nodules. It has already been used successfully for the treatment of malignancy in the liver, lung and kidneys [9]. The technique's effectiveness for volume reduction in thyroid nodules has been proven in various studies $[1,10,11]$. Nevertheless, these nonsurgical minimally invasive treatments have their limits, especially, for the treatment of very large nodular goiters. As thermal ablation therapy would need a couple of treatment sessions and would be a lot more time-consuming, it is fairly difficult to use thermal ablation as monotherapy for the treatment of very large nodular goiters. For example, HIFU has a treatment time of about 12 minutes per milliliter, whereas the treatment time is about 30 minutes for RFA and about 15 minutes for MWA for a nodule volume of $4-5 \mathrm{ml}$. MWA was chosen for combined therapy as it yielded better results regarding the ablation zone, treatment time and had less side effects in comparison to other thermoablative techniques [12-14].

It is well established that RIT causes a volume reduction in an acceptable magnitude. Nevertheless, it is also well known that volume reduction is a slow process and improvement can only be observed 3 to 36 months after treatment whereas MWA immediately destroys the total nodule volume during therapy. Therefore, necrotic tissue and the onset of volume reduction can be observed instantly after treatment. Patients feel a relief of subjective symptoms, e.g. tension or swallowing problems. Another important aspect is the side effect-benefit ratio that has to be considered beyond a specific amount of calculated required radioiodine dose. Radioiodine-131 should only be administered up to a maximum level (in this institution: $1300 \mathrm{MBq}$ ) to avoid adverse events such as trachea stenosis and to reduce unreasonably dangerous irradiation to healthy tissue. According to Marinelli et al. [15], a reduced amount of radioiodine-131 leads to a reduced radiation dose and therefore to an insufficient treatment (or the necessity of a second RIT). The combination of MWA and RIT allows a more effective treatment in cases of large nodular goiters that could not have been sufficiently treated by a RIT monotherapy due to calculated required radioiodine doses beyond $1300 \mathrm{MBq}$. The pre-RIT reduction of thyroid volume by MWA leads to a reduction of required radioiodine dose and therefore enables a more sufficient and safer RIT. Based on the formula by Marinelli et al., the required activity can be decreased by reducing the target volume:

Activity $[\mathrm{MBq}]=\frac{[\text { Dose }[\mathrm{Gy}] \times \text { Mass of target volume }[\mathrm{g}]]}{\text { constant } \times \max . \text { uptake }[\%] \times \text { eff. half-life }[\mathrm{d}}$ *Mass of target volume $=$ vital thyroid volume - MWA ablated tissue (avital)

In an earlier study, the combined therapy showed promising results in volume reduction ( $24 \pm 6 \%$ ), hospitalization time reduction $(28 \pm 6 \%$ ), which is important in Germany, and therefore a potential reduction of administered I-131-dose (24 $\pm 6 \%$ ) [16]. This study aims at assessing the efficacy of the combined MWA and I-131 treatment of benign thyroid diseases at a 3-month follow-up (3MFU), focusing on the development of thyroid function and thyroid volume.

\section{Materials and Methods \\ $\nabla$}

\section{Patients}

15 patients ( 7 men and 8 women, median age: 55 years (27- 79 years)) matching the entry criteria were recruited for the study. Every patient had one nodule. No previous surgeries or radioiodine therapies had taken place. 14 patients were treated for goiters, 1 because of Graves' disease. 8 out of the 14 patients suffering from goiter, additionally, had autonomous tissue.

The entry criteria were either: (a) growing goiters, (b) symptomatic benign thyroid nodules; hot, cold or indifferent (c) local compression symptoms, (d) cosmetic concerns, (e) high operative risk, (f) previous thyroidectomy or (g) refusal of surgery. The exclusion criteria were: (a) thyroids with retrosternal growth, (b) histological evidence for follicular proliferation or malignancy, (c) conspicuous Tc-99m-MIBI uptake in cold nodules, (c) abnormal calcitonin measurement as evidence for medullary thyroid cancer, (d) critical positions near vessels, trachea, esophagus or nerves. 
The local ethics committee approved the study protocol and written informed consent was obtained from all subjects before starting therapy.

\section{Chronological overview \\ 1. Enrollment assessments \\ 2. Radioiodine uptake test (RIUT) - one week before therapy \\ 3. MWA, re-evaluation assessments, RIT - on the same day \\ 4. 3-month follow-up (6-month follow-up)}

\section{Assessments}

All patients underwent pre-therapy assessments, post-MWA assessments and assessments at 3MFU including US, laboratory tests and functional imaging with Tc-99m-Pertechnetat and in some cases Tc-99m-Methoxy-isobutyl-isonitril (MIBI).

\section{Ultrasound evaluation}

US imaging was conducted with a B-mode ultrasound scanner (Sonix Touch Ultrasound system, Ultrasonix Medical Corporation, Richmond, Canada) to evaluate the volume, size, and composition of the nodules and thyroids.

\section{Laboratory evaluation}

All serum levels were determined with commercially available immunoradiometric assay (IRMA) and radioimmunoassay (RIA) kits.

A complete thyroid hormone status, including triiodothyronine (T3) determined by RIA (T3[I-125] RIA Kit, Izotop, Budapest, Hungary), thyroxine (T4) determined by RIA (T4[I-125] RIA Kit, Izotop, Budapest, Hungary), thyrotropin (TSH) determined by IRMA (SELco ${ }^{\circledR}$ TSH rapid, Medipan GmbH, Dahlewitz, Germany) and thyroglobulin (Tg) determined by IRMA (Riason ${ }^{\circledR}$ Tg c.t., Iason $\mathrm{GmbH}$, Graz-Seiersberg, Austria) was analyzed.

Moreover, antibody detection tests were performed, namely against thyroid peroxidase (TPOAb) determined by RIA (antiTPO magnum, Medipan GmbH, Dahlewitz, Germany), thyreoglobulin (TgAb) determined by RIA (anti-Tg magnum, Medipan $\mathrm{GmbH}$, Dahlewitz, Germany) and thyrotropin receptor (TRAb) determined by RIA (TRAb Human RIA, Brahms GmbH, Henningsdorf, Germany).

Reference ranges were defined as follows:

T3: 1.0 - $3.3 \mathrm{nmol} / \mathrm{L} ; \mathrm{T} 4: 55$ - $170 \mathrm{nmol} / \mathrm{L} ; \mathrm{TSH}: 0.3$ - $4.0 \mathrm{mE} / \mathrm{L} ; \mathrm{Tg}$ : $2-70 \mathrm{ng} / \mathrm{mL}$; TPOAb: <50 IU/ml; TgAb: <50 IU/ml; TRAb: $<1.5 \mathrm{IU} / \mathrm{L}$.

\section{Functional imaging}

All patients received Tc-99m-pertechnetate and in some cases Tc-99m-MIBI-scans. Scintigraphic images were taken 20 minutes after administration of $75 \mathrm{MBq}$ Tc-99m-pertechnetate and recorded with a scintillation camera (Mediso Nucline ${ }^{\circledR} \mathrm{TH} / 22$ ). Patients with "cold" nodules were re-evaluated with a Tc-99m-MIBI scan to exclude malignancy. Scintigraphic images were taken 10 and 60 minutes after administration of $500 \mathrm{MBq}$ Tc-99m-MIBI.

\section{Radioactive iodine uptake test (RIUT)}

The RIUT was performed one week before combined therapy as described in the guidelines by Dietlein et al. [17].

After administration of a test capsule with a dose of $2-4 \mathrm{MBq}$ I131 , the course of activity was monitored by measuring the residual activity in the thyroid 2, 48 and 96 hours after administration. From these measurements the individual effective half-life and extrapolated maximum accumulation (ema), defined as the extrapolation of monoexponential iodine excretion of the thyroid to the time of application $(t=0)$, were calculated.

\section{Combined therapy of MWA and RIT \\ Microwave ablation equipment}

The microwave unit consists of a microwave generator, a flexible low-loss coaxial cable and an internally cooled shaft antenna. The system used (Avecure MWG881, Med-Waves, Inc. San Diego, CA) works in a frequency range of 902 to $928 \mathrm{MHz}$ and generates maximum temperatures of approximately $140{ }^{\circ} \mathrm{C}$. The target temperature was $60-80^{\circ} \mathrm{C}$ with an output of $24-28 \mathrm{~W}$. The frequency is automatically controlled with real-time temperature and reverse-power feedback during ablation to optimize ablation safety, efficiency, energy transfer and predictability. According to individual aspects of each patient, three different probes (14$16 \mathrm{G}$; small, medium or large) with diverging ablation areas can be used. The ablation field varies from $1 \mathrm{~cm}$ to $4 \mathrm{~cm}$.

\section{Microwave ablation procedure}

At first the patient was placed in a supine position with a hyperextended neck. Before inserting the microwave probe, aseptic conditions were assured and the nodule volume was reevaluated with ultrasound ( Fig.1A). After determination of the best puncture site, local anesthesia (Scandicain 1\%) was applied and the skin was incised by $1-2 \mathrm{~mm}$ ( $\bullet$ Fig. 1B). The trans-isthmic approach is commonly used for thermal ablation for thyroid nodules, making it easier to observe the microwave antenna and its surroundings (nerves and vascular structures). The probe was positioned under ultrasound guidance. The method assures that the microwaves are inserted directly into the nodule ( $\bullet$ Fig. 1C) without damaging the danger triangle, including the recurrent laryngeal nerve, esophagus and trachea. The generator was turned on as soon as the antenna was precisely positioned.

By the dipole moment of water molecules, oscillation and, consequently, heat are created in the tissue surrounding the antenna, thereby inducing irreversible coagulation necrosis. During the procedure the temperature was monitored to avoid excessive heat and real-time ultrasound was used to assure the correct position of the probe. At run time, ablation real-time ultrasound also enabled the observation of echo transformation in the nodule. Heat induction was stopped as soon as the whole nodule was hyperechogenic and covered with microbubbles, both of which symbolize heat development ( $\bullet$ Fig. 1 D, E). In larger nodules the tip of the antenna can be repositioned to destroy the entire nodule volume ( $\bullet$ Fig. 1F). Furthermore, internal fluid in cystic nodules should be aspirated before ablation. During treatment the pain status and well-being should be observed and, if necessary, power can be reduced or turned off for a few seconds. To verify no injury to the laryngeal nerve, the physician talked to the patient to asses changes of phonation.

\section{Radioiodine therapy}

Four to five hours after the treatment and re-evaluation of nodule and thyroid volume, Tc-99m-pertechnetate uptake and laboratory values, the physician administered the I-131 capsule with the specific individually calculated I-131 dose. Patients treated with methimazole (MMI) were asked to discontinue taking the medication to obtain suppressed levels of TSH at the time of I-131 administration. I-131 therapeutic activity was aimed at delivering $150 \mathrm{~Gy}$ to patients with a goiter and $250 \mathrm{~Gy}$ to the patient with Graves' disease. 

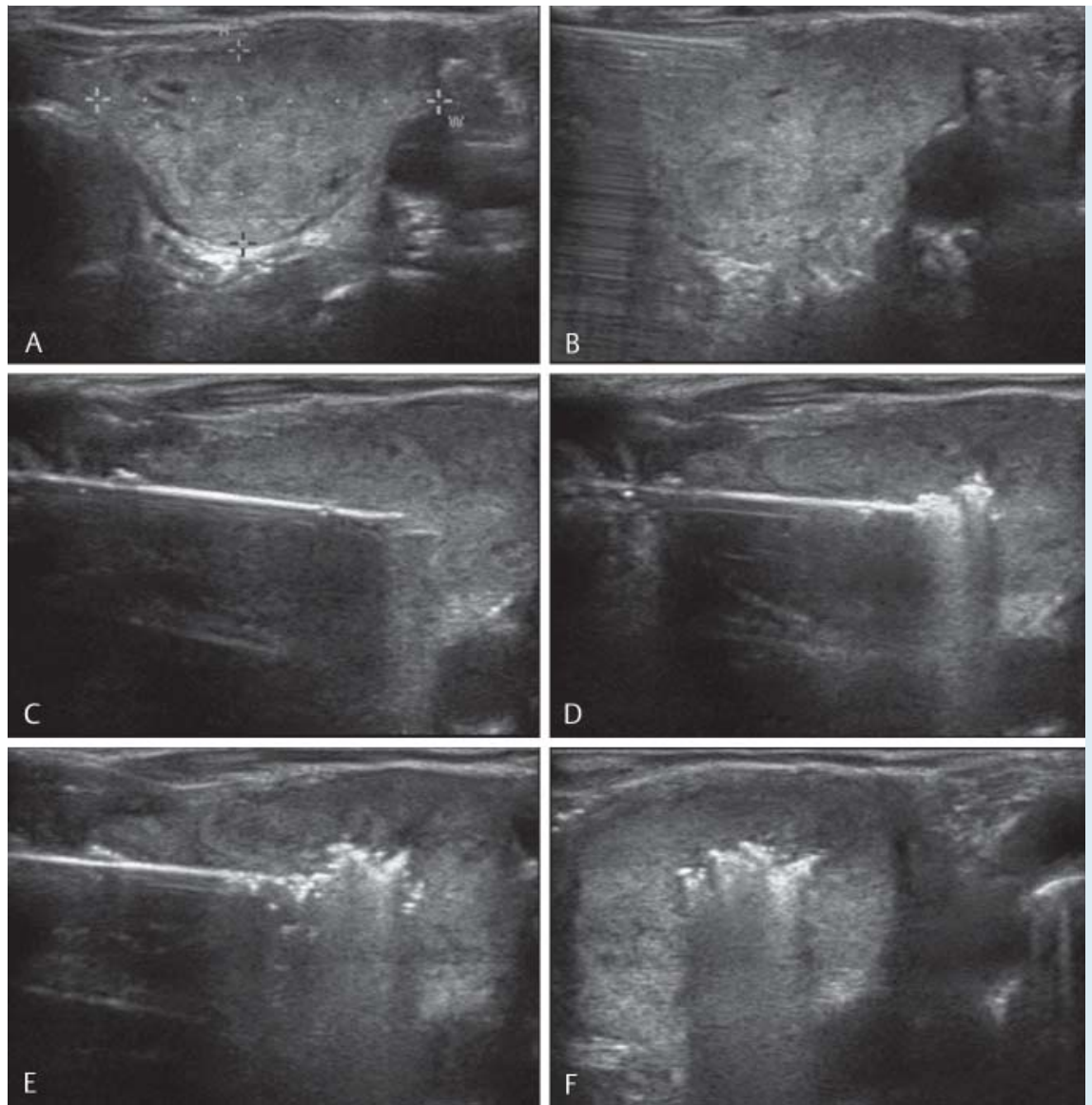

Fig. 1 A Ultrasound examination to locate and recalculate a thyroid nodule. B Subcutaneous and intracapsular (thyroid) infiltration anesthesia with Scandicain $(0.9 \% ; 10 \mathrm{ml})$ to prevent pain and create a fluid protection area, protecting vital structures of the neck (trachea, esophagus, carotid artery and nerve). C Positioning of the internally cooled microwave antenna. D, E During treatment hyperchogenic areas and microbubbles surrounding the antenna tip can be observed. $\mathbf{F}$ Ultrasound guidance allows accurate replacement of the antenna by moving the tip of the antenna backwards and relocating it in a non-ablated area of the nodule.

Abb. 1 A Ultraschalluntersuchung zur Lokalisations- und Größenbestimmung des Knotens. B Um Schmerzen vorzubeugen und einen flüssigen Schutzwall für die Halsorgane (A. carotis, Nerven, Trachea und Ösophagus) zu schaffen, wird subkutan und auch in die Schilddrüsenkapsel Scandicain $(0,9 \% ; 10 \mathrm{ml})$ gespritzt. C Positionierung der gekühlten Mikrowellenantenne. D, E Während der Behandlung kann man an der Spitze der Antenne hyperechogene Regionen und "microbubbles" erkennen. F Unter Ultraschallsicht ist es möglich die Antennenspitze zurück zu ziehen und akkurat in einen nicht-abladierten Teil des Knotens vorzuschieben.

\section{Results}

$\boldsymbol{\nabla}$

\section{Volume reduction}

In every patient the nodule was completely destroyed by MWA. A comparison of thyroid volumes before therapy and at 3MFU ( Fig. 2) shows a significant mean volume reduction of $26.4 \mathrm{ml}$ $\pm 7.9 \mathrm{ml}$, implying a mean relative reduction of $30.5 \% \pm 4.6 \%$ $(\mathrm{p}<0.05)$ (range of volume reduction: $18-47 \%)$. Table 1 presents a detailed list of volume reduction achieved in every patient. $\bullet$ Fig. 3 depicts the volume reduction achieved in patient no. 10 .

\section{Activity and hospitalization time (HT) reduction}

Dosimetric results are summarized in 0 Table 2.

The mean required activity without reducing target volume by MWA was $2116 \pm 701 \mathrm{MBq}$, while the mean required activity utilizing MWA prior to RIT was $1553 \pm 537 \mathrm{MBq}$. This implies a mean absolute activity reduction of $563 \pm 102 \mathrm{MBq}$ and a relative reduction of $26.6 \% \pm 4.8 \%(\mathrm{p}<0.05)$ using the combined therapy. Additionally, there was a significant reduction of hospitalization time for some patients. The mean hospitalization time for classic RIT was $6.5 \pm 1.8$ days to reach the permissible value of $250 \mathrm{MBq}$ to be discharged from hospital, whereas the hospitalization time for combined therapy was $4.5 \pm 1.4$ days. This reflects a mean time reduction of $2 \pm 0.7$ days and a relative reduction of $30.9 \% \pm 19.9 \%(\mathrm{p}<0.05)$.

\section{Blood tests}

All serum levels before MWA and at 3MFU are summarized in - Table 3. T3 and T4 levels remained within normal limits in all

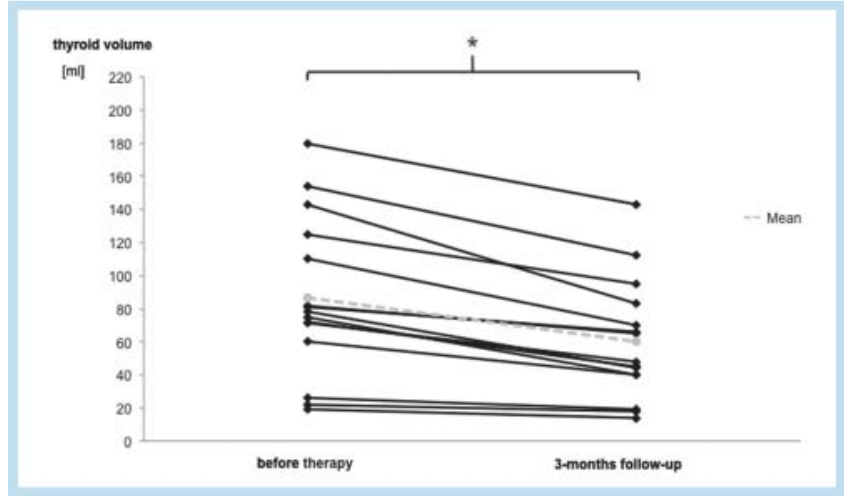

Fig. 2 Comparison of thyroid volumes before combined therapy and at 3month follow-up $\left({ }^{*} \mathrm{p}<0.05\right)$.

Abb. 2 Vergleich der Schilddrüsenvolumen vor der Kombinationstherapie und bei der 3-monatigen Kontrolluntersuchung ( $\left.{ }^{*} \mathrm{p}<0,05\right)$.

patients. TSH levels improved or remained in normal limits in 13 out of 15 patients. Before treatment and at 3MFU, two patients (no. 6 and no.15) showed values below the euthyroid range. However, the patients had no signs of hyperthyroidism. In all patients Tg levels were elevated significantly in the measurements after MWA but decreased back to baseline values at 3MFU.

\section{Antibody measurement}

Antibody measurements are summarized in 0 Table 4. The patient treated for Grave's disease (no.4) showed increased anti- 


\begin{tabular}{|lllllll|}
\hline patient & disease & $\begin{array}{l}\text { age } \\
{[\mathbf{a}]}\end{array}$ & $\begin{array}{l}\text { pre- therapy } \\
\text { thyroid volume } \\
{[\mathbf{m l}]}\end{array}$ & $\begin{array}{l}\text { (ablated) } \\
\text { nodule volume } \\
{[\mathbf{m l}]}\end{array}$ & $\begin{array}{l}\text { 3MFU thyroid } \\
\text { volume } \\
\text { [ml] }\end{array}$ & $\begin{array}{l}\text { volume } \\
\text { reduction } \\
\text { [ml] }\end{array}$ \\
\hline 1 & Goiter + MFA & 54 & 22 & 4 & 18 & 4 \\
\hline 2 & Goiter & 66 & 125 & 27 & 95 & 30 \\
\hline 3 & Goiter & 75 & 26 & 6 & 19 & 85 \\
\hline 4 & Graves' disease & 49 & 19 & 2 & 14 & 5 \\
\hline 5 & Goiter + DPD & 58 & 154 & 31 & 112 & 42 \\
\hline 6 & Goiter + DPD & 57 & 180 & 32 & 143 & 32 \\
\hline 7 & Goiter & 79 & 81 & 9 & 66 & 17 \\
\hline 8 & Goiter & 55 & 78 & 25 & 44 & 26 \\
\hline 9 & Goiter & 53 & 71 & 23 & 48 & 23 \\
\hline 10 & Goiter & 62 & 143 & 59 & 83 & 61 \\
\hline 11 & Goiter + MFA & 27 & 82 & 19 & 65 & 12 \\
\hline 12 & Goiter + MFA & 43 & 72 & 27 & 45 & 19 \\
\hline 13 & Goiter + DPD & 47 & 60 & 20 & 40 & 40 \\
\hline 14 & Goiter + MFA & 49 & 75 & 30 & 40 & 25 \\
\hline 15 & Goiter + DPD & 54 & 110 & 30 & 70 & 40 \\
\hline average & & 55.2 & $86.5 \pm 24.2^{1}$ & $22.9 \pm 7.2^{1}$ & $60.1 \pm 18.3^{1}$ & $30.7 \pm 10.7^{1}$ \\
\hline
\end{tabular}

Table 1 Detailed list of the patient cohort including disease, age, pre-therapy thyroid volume, (ablated) nodule volume, 3 month follow-up (3MFU) thyroid volume and volume reduction since the beginning of treatment.

Tab. 1 Detaillierte Liste der Patientenkohorte mit Erkrankung, Schilddrüsenvolumen vor der Therapie, (abladiertes) Knotenvolumen, Schilddrüsenvolumen nach der 3-Monats-Kontrolle (3MFU) und Volumenreduktion seit Therapiebeginn.

MFA = multifocal autonomy, DPD = disseminated Plummer's disease. ${ }^{1} \mathrm{p}<0.05$
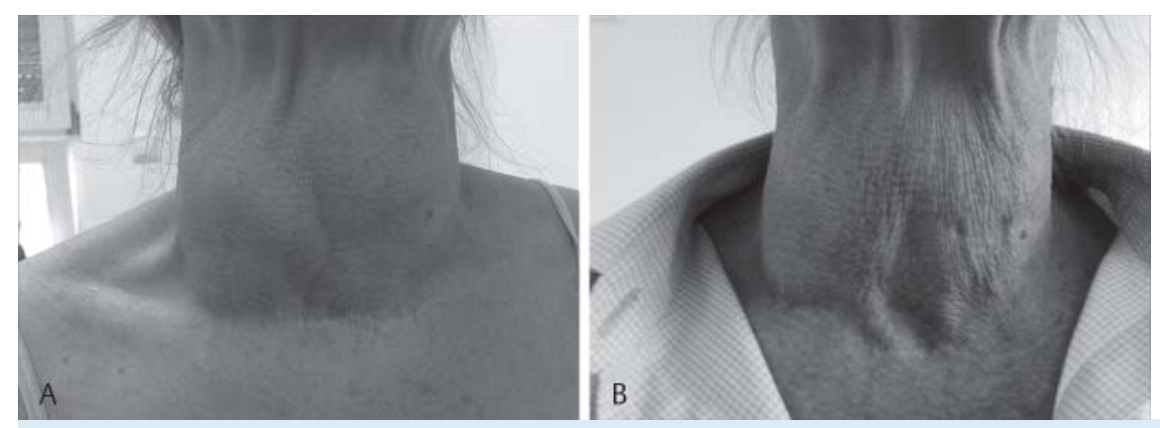

Fig. 3 Illustration of the neck region (patient no. 10; 0 Table 1); goiter volume was reduced from $143 \mathrm{ml}$ to $82 \mathrm{ml}$. A Goiter during enrollment assessments. B Goiter at 3-month follow-up; notice the volume reduction regarding especially the fossa jugularis and the skin retraction.

Abb. 3 Darstellung der Halsregion (Patient Nr. 10; 0 Tab. 1); das Strumenvolumen wurde von $143 \mathrm{ml}$ auf $82 \mathrm{ml}$ reduziert. A Struma während der Voruntersuchung. B Struma bei der 3-monatigen Kontrolluntersuchung. Die Volumenreduktion ist besonders bei der Betrachtung der Fossa jugularis, der Einziehung der Haut und der Hautfalten erkennbar.

Tg, TRAb and anti-TPO levels before treatment and at 3MFU. The TSH level in this patient increased to normal levels 3 months after treatment. Another patient had elevated anti-TPO before treatment and at follow-up, showing no symptoms of Hashimoto's thyroiditis or Graves' disease before or after therapy. The TRAb value was elevated at 3MFU for one patient (no.7). Due to the combination of MWA and RIT, it cannot be clearly determined whether TRAb development is a result of MWA or RIT. Correspondingly, only one patient was found to develop TRAb during 3MFU, nevertheless, staying euthyroid.

\section{Complications}

No serious complications occurred during treatment. There were no interruptions and discomfort stayed at a minimum.

The following complications were reported for MWA: mild pain during the procedure (2/15), mild superficial hematomas due to pressure of the US probe (1/15) and first-degree burns alongside the puncture channel which disappeared within a couple of days (1/15). Ultrasound assessments assured that the hematomas did not reach deeper tissue layers. Serious complaints, such as swallowing problems, vagal reactions or subjectively noticeable voice changes, did not occur.

\section{Discussion}

Surgery and RIT are often recommended as the first option for the therapy of nodular goiters. As both of the therapies involve drawbacks and complications, e.g. scar formation, nerve lesions, hypothyroidism or thyroiditis $[1,18]$, and surgery is often contraindicated or refused by older patients due to high surgical risk because of cardiopulmonary diseases, attention is increasingly focused on non-surgical alternative treatments.

In the last two decades several nonsurgical, image-guided, minimally invasive approaches including RFA [7, 19], LAT [8, 20], PEIT [21], HIFU [8, 22] and MWA [1, 10, 11, 23] have been developed for the efficient treatment of thyroid nodules, without the risk of general anesthesia and while preserving normal thyroid function. Nevertheless, there is barely any research and results on thermal ablation of very large goiters as the treatment is quite time-consuming, needs more treatment sessions and is accompanied by increased discomfort [24]. In an evaluation of the efficiency of LA for thyroid nodules, Spiezia et al. [25] recommends adding radioiodine therapy for the effective treatment of very large nodular goiters. However, large goiters are frequently seen as a relative contraindication for the utilization of RIT as the risk 
Table 2 Characteristics of dosimetry: Target dose, calculated I-131-dose and calculated hospitalization time (HT) for combined therapy and classic RIT for every patient is given. The combined therapy yielded a reduction of I-131-dose by $26.6 \% \pm 4.8 \%(\mathrm{p}<0.05)$ and a reduction of hospitalization time by $30.9 \%$ $\pm 19.9 \%(\mathrm{p}<0.05)$ compared to classic RIT.

Tab. 2 Charakteristika der Dosimetrie: Es werden Zieldosis, berechnete I-131-Therapieaktivität (TA) und die berechnete Krankenhausliegedauer (HT) für die Kombinationstherapie und für die klassische RIT für jeden Patienten gezeigt. Die Kombinationstherapie erzielte eine Senkung der I-131-TA um 26,6\% $\pm 4,8 \%$ $(p<0,05)$ und eine Senkung der HT um 30,9\% $\pm 19,9 \%(p<0,05)$ im Vergleich zur klassischen RIT.

\begin{tabular}{|c|c|c|c|c|c|c|}
\hline patient & disease & $\begin{array}{l}\text { target dose } \\
{[G y]}\end{array}$ & $\begin{array}{l}\text { calculated I-131-dose RIT } \\
\text { [MBq] }\end{array}$ & $\begin{array}{l}\text { calculated I-131-dose } \\
\text { MWA + RIT } \\
\text { [MBq] }\end{array}$ & $\begin{array}{l}\text { calculated HT RIT } \\
\text { [days] }\end{array}$ & $\begin{array}{l}\text { calculated HT } \\
\text { MWA + RIT } \\
\text { [days] }\end{array}$ \\
\hline 1 & Goiter + MFA & 150 & 595 & 493 & 3 & 2 \\
\hline 2 & Goiter & 150 & 3043 & 2381 & 10 & 8 \\
\hline 3 & Goiter & 150 & 377 & 293 & 3 & 2 \\
\hline 4 & Graves' disease & 250 & 553 & 507 & 3 & 3 \\
\hline 5 & Goiter + DPD & 150 & 2865 & 2285 & 7 & 5 \\
\hline 6 & Goiter + DPD & 150 & 2579 & 2139 & 14 & 11 \\
\hline 7 & Goiter & 150 & 1410 & 1248 & 7 & 5 \\
\hline 8 & Goiter & 150 & 1669 & 1199 & 6 & 3 \\
\hline 9 & Goiter & 150 & 1151 & 768 & 5 & 3 \\
\hline 10 & Goiter & 150 & 2270 & 1270 & 12 & 7 \\
\hline 11 & Goiter + MFA & 150 & 5650 & 4362 & 7 & 5 \\
\hline 12 & Goiter + MFA & 150 & 1294 & 816 & 6 & 2 \\
\hline 13 & Goiter + DPD & 150 & 1758 & 1172 & 4 & 2 \\
\hline 14 & Goiter + MFA & 150 & 3000 & 1800 & 2 & 2 \\
\hline 15 & Goiter + DPD & 150 & 3520 & 2560 & 9 & 7 \\
\hline average & & & $2.115 \pm 701^{1}$ & $1.552 \pm 537^{1}$ & $6.5 \pm 1.8^{1}$ & $4.5 \pm 1.4^{1}$ \\
\hline
\end{tabular}

${ }^{1} \mathrm{p}<0.05$

Table 3 Laboratory tests before combined therapy and at 3-month follow-up (3MFU). Additionally, hTg levels after MWA are noted as these increased strongly.

Tab. 3 Blutwerte vor der Kombinationstherapie und bei der 3-monatigen Kontrolluntersuchung (3MFU). Zusätzlich wurden die hTg-Werte nach der MWA angegeben, da sie stark anstiegen.

\begin{tabular}{|c|c|c|c|c|c|c|c|c|c|}
\hline \multirow[t]{2}{*}{ patient } & \multicolumn{2}{|c|}{$\begin{array}{l}\text { T3 [nmol/l] } \\
(1.0-3.3)\end{array}$} & \multicolumn{2}{|c|}{$\begin{array}{l}\text { T4 [nmol/l]] } \\
(55-170)\end{array}$} & \multicolumn{2}{|c|}{$\begin{array}{l}\text { TSH-basal [mE/l] } \\
(0.3-4.0)\end{array}$} & \multicolumn{3}{|c|}{$\begin{array}{l}\mathrm{hTg}[\mathrm{ng} / \mathrm{ml}] \\
\text { (Athyreote < } 1 \text { ) }\end{array}$} \\
\hline & $\begin{array}{l}\text { before } \\
\text { therapy }\end{array}$ & 3MFU & $\begin{array}{l}\text { before } \\
\text { therapy }\end{array}$ & 3MFU & $\begin{array}{l}\text { before } \\
\text { therapy }\end{array}$ & 3MFU & $\begin{array}{l}\text { before } \\
\text { therapy }\end{array}$ & after MWA & 3MFU \\
\hline 1 & 1.5 & 1.8 & 78 & 84 & 0.59 & 0.99 & 22 & 75 & 75 \\
\hline 2 & 1.9 & 2.2 & 64 & 75 & 0.45 & 0.29 & 111 & 1544 & 472 \\
\hline 3 & 2.1 & 2.0 & 91 & 89 & 2.94 & 0.72 & 7536 & 23970 & 2743 \\
\hline 4 & 1.2 & 1.1 & 75 & 89 & 0.16 & 0.65 & 20 & 17 & 32 \\
\hline 5 & 1.9 & 2.1 & 87 & 101 & 1.2 & 0.38 & 2037 & 32051 & 1396 \\
\hline 6 & 1.6 & 1.9 & 79 & 68 & 0.08 & 0.05 & 484 & 2808 & 364 \\
\hline 7 & 1.8 & 1.4 & 89 & 122 & 0.38 & 1.4 & 62 & 881 & 85 \\
\hline 8 & 1.7 & 1.6 & 55 & 72 & 0.16 & 0.65 & 521 & 8565 & 44 \\
\hline 9 & 1.9 & 1.8 & 99 & 89 & 0.44 & 1.03 & 132 & 3108 & 176 \\
\hline 10 & 1.5 & 1.5 & 73 & 86 & 2.69 & 1.03 & 157 & 14412 & 93 \\
\hline 11 & 5.0 & 1.4 & 56 & 62 & 0.02 & 0.73 & 15 & 579 & 29 \\
\hline 12 & 1.5 & 1.3 & 85 & 71 & 0.06 & 1.24 & 70 & 129 & $x$ \\
\hline 13 & 2.7 & 2.3 & 84 & 87 & 0.33 & 0.68 & 9 & 34 & 58 \\
\hline 14 & 1.7 & 1.7 & 108 & 75 & 0.07 & 0.97 & 156 & 4931 & 330 \\
\hline 15 & 1.4 & 1.7 & 60 & 86 & 0.26 & 0.03 & 66 & 2935 & 23 \\
\hline $\mathrm{MV} / \mathrm{A}$ & $1.7 / 2.0$ & $1.7 / 1.7$ & 79/79 & $86 / 84$ & $0.3 / 0.7$ & $0.7 / 0.7$ & $111 / 760$ & $2808 / 6403$ & 881 \\
\hline
\end{tabular}

MV: median value, A: average, $\mathrm{x}$ : not evaluated, $\mathrm{T} 3=$ triiodthyronine, $\mathrm{T} 4=$ thyroxine, $\mathrm{TSH}=$ thyrotropin, $\mathrm{hT} \mathrm{g}=$ thyroglobulin; reference ranges in brackets.

$\mathrm{T} 3=$ Triiodthyronin, $\mathrm{T} 4$ = Thyroxin, $\mathrm{TSH}=$ Thyreotropin, $\mathrm{hTg}=$ Thyreoglobulin; Referenzbereiche in Klammern.

of local symptoms, hypothyroidism and autoimmune thyroiditis is increased and the volume reduction is slow [26, 27]. For these patients higher activities of I-131 are required. As shown in 0 Table 1, 2, preceding thermal ablative treatment not only accelerates the reduction of total thyroid volume but also reduces the target volume and, consequently, activity for I-131 therapy.
Until now, there have been two studies analyzing the impact of combined therapies on nodular goiters. One reports efficient treatment using ultrasound-guided PEIT combined with RIT in patients with toxic thyroid nodules [28]. PEIT, however, presents limitations in solid nodules and is currently recommended for cystic lesions only [29]. Chianelli et al. [5] combined LAT and RIT 
Table 4 Antibody levels before combined therapy, after microwave ablation (MWA) and at 3-month follow-up (3MFU).

Tab. 4 Antikörperblutwerte vor der Kombinationstherapie, nach der Mikrowellenablation (MWA) und bei der 3-monatigen Kontrolluntersuchung (3MFU).

\begin{tabular}{|c|c|c|c|c|c|c|c|c|c|}
\hline \multirow[t]{2}{*}{ patient } & \multicolumn{3}{|c|}{$\begin{array}{l}\text { TRAb } \\
\text { (pos. > 1.5) }\end{array}$} & \multicolumn{3}{|c|}{$\begin{array}{l}\text { TgAb } \\
\text { (pos. > 50) }\end{array}$} & \multicolumn{3}{|c|}{$\begin{array}{l}\text { TPOAb } \\
\text { (pos. >50) }\end{array}$} \\
\hline & $\begin{array}{l}\text { before } \\
\text { therapy }\end{array}$ & after MWA & 3MFU & $\begin{array}{l}\text { before } \\
\text { therapy }\end{array}$ & after MWA & $3 \mathrm{MFU}$ & $\begin{array}{l}\text { before } \\
\text { therapy }\end{array}$ & after MWA & $3 \mathrm{MFU}$ \\
\hline 1 & 0.09 & 0.07 & 0.78 & 1 & 12 & 12 & 10 & 10 & 10 \\
\hline 2 & 0.10 & 0.20 & 0.31 & 12 & 6 & 16 & 6 & 13 & 12 \\
\hline 3 & 0.00 & 0.20 & 0.34 & 2 & 3 & 5 & 10 & 8 & 5 \\
\hline 4 & 4.40 & 3.60 & 17.90 & 190 & 135 & 364 & 1860 & 1561 & 7036 \\
\hline 5 & 0.00 & 0.00 & 0.00 & 2 & 3 & 15 & 4 & 10 & 4 \\
\hline 6 & 0.10 & 0.83 & 0.20 & 9 & 9 & 11 & 241 & 296 & 263 \\
\hline 7 & 0.20 & 0.60 & 4.20 & 13 & 9 & 9 & 9 & 8 & 18 \\
\hline 8 & 0.50 & 0.10 & 0.00 & 5 & 7 & 10 & 11 & 14 & 10 \\
\hline 9 & 0.50 & 0.00 & 0.00 & 3 & 6 & 10 & 12 & 11 & 6 \\
\hline 10 & 0.30 & 0.18 & 0.00 & 7 & 6 & 9 & 11 & 9 & 8 \\
\hline 11 & 0.27 & 0.00 & 0.50 & 6 & 3 & 4 & 5 & 4 & 7 \\
\hline 12 & 0.00 & 0.35 & 0.00 & 4 & 5 & 3 & 7 & 10 & 4 \\
\hline 13 & 0.29 & 0.60 & 0.00 & 3 & 6 & $x$ & 5 & 11 & $x$ \\
\hline 14 & 0.05 & 0.00 & 0.00 & 2 & 2 & 5 & 10 & 9 & 9 \\
\hline 15 & 0.50 & 0.30 & 0.05 & 3 & 3 & 4 & 4 & 5 & 6 \\
\hline $\mathrm{MV} / \mathrm{A}$ & $0.2 / 0.5$ & $0.2 / 0.5$ & $0 / 1.6$ & $4 / 17$ & $6 / 14$ & $10 / 34$ & $10 / 14$ & $10 / 132$ & \\
\hline
\end{tabular}

MV: median value, A: average, $x$ : not evaluated, $\operatorname{TgAb}=$ thyroglobulin antibodies, TRA $b=$ thyrotropin receptors antibodies, TPOAb $=$ thyroid peroxidase antibodies; reference ranges in brackets.

TgAb = Thyreoglobulin-Antikörper, TRAb = Thyreotropinrezeptor- Antikörper, TPOAb = Thyreoperoxidase-Antikörper; Referenzbereiche in Klammern.

for the treatment of toxic nodular goiters and obtained a reduction of $71.3 \pm 13.4 \%$ in nodule volume and a reduction of 21.1 $\pm 8.1 \%$ in administered radioiodine activity. Nevertheless, LAT presents limitations in autonomously functioning thyroid nodules. Chianelli claims that the favorable results are inconsistent, and the normalization of thyroid function usually requires repeated treatment sessions [30]. MWA is applicable on any kind of nodule, i. e., hot, cold, indifferent, cystic, solid or mixed, and has various advantages compared to the above-mentioned techniques. A previous study [16] introduced the positive results of combined MWA and radioiodine therapy. The statistically significant thyroid volume reduction of $24 \pm 6 \%(\mathrm{p}<0.05)$, the reduction in administered I-131 activity by $24 \pm 6 \%(\mathrm{p}<0.05)$, the good treatment response and the small number of adverse events demonstrated that the combined MWA and RIT therapy could be an effective and safe conservative approach to treating large nodular goiters. An additional study approved the therapy for the treatment of patients with simultaneously hypo- and hyperfunctioning thyroid nodules [31].

The presented study focused on thyroid volume and thyroid function at 3MFU. Regarding surgery, especially thyroidectomy, hypothyroidism cannot be prevented and lifelong substitution of thyroid hormones is necessary. Concerning the impact of minimally invasive techniques on thyroid functions, there have only been a few reports. Transient hyperthyroidism is described after RFA [32]. Hypothyroidism is reported more often, especially, subsequent to PEIT for the treatment of autonomously functioning nodules [33]. After LAT and RFA, hypothyroidism occurs rarely [34]. In a few cases hypothyroidism is also reported after radioiodine therapy. This contributes to the inevitable impact of I-131 on the entire thyroid gland [35].

A recent 3-month follow-up study proved that MWA does not affect thyroid function in patients with benign thyroid nodules [36]. As hypothyroidism often develops after a period of three months post-therapy, data has to be treated with caution and it cannot be completely excluded that hypothyroidism will occur. However, the 4 out of 15 patients in this study that went through a 6-month follow-up (6MFU) did not develop hypothyroidism. Laboratory parameters TSH, T3 and T4 did not change significantly after MWA or at 3MFU/6MFU of the combined therapy $(\mathrm{p}<0.05)$ ( $\bullet$ Table 3). Patient no. 4 and no. 8 even improved to normal TSH levels at 3MFU. This demonstrates the positive effect of combined therapy on thyroid function. For one patient (no.6) the TSH values before and 3 months after treatment were lower than normal levels without showing any signs of hyperthyroidism. Consequently there is no correlation between therapy and the low levels. In this case therapy had no effect on thyroid function, positive or negative.

However, for all patients the thyroglobulin (Tg) levels were elevated significantly in the measurements after MWA but decreased back to baseline at 3MFU. Tg is used for measurements of thyroid tissue injury, such as growth factor and tumor marker. One explanation might be that $\mathrm{Tg}$ values increased after ablation due to injured necrotic thyroid tissue and recovered during the $3 \mathrm{MFU}$ period due to healing processes. Similar findings were reported by Valcavi et al. [37] after LA of benign thyroid nodules. It cannot be clearly determined whether the elevated TRAb development in patient no. 7 ( Table 4) at 3MFU is a result of MWA or RIT. The further planned procedure would have been to treat the developed Graves' disease with RIT. Fortunately, this was not necessary as pre-RIT assessments showed that the TRAb level decreased back to the normal range. Nevertheless, Monzani et al. [33] concluded that a massive release of partially denatured TSH receptors could be a reason for the development of increasing TRAb levels after ablation of toxic nodules with PEIT. Therefore, an immunization process caused by MWA cannot be excluded completely. Nygaard et al. [38] demonstrated that immunization processes can be triggered by I-131 therapy, not 
only related to radiation thyroiditis but also as a Graves'-like hyperthyroidism induced by TRAb. Finally, it can reasonably be assumed that the elevated TRAb level was an effect of RIT as there is more evidence for antibody developments after RIT [38, 39] and hardly any for MWA. This case has to be intensively investigated and observed in future studies.

Furthermore, it is important for future therapy to investigate if and to what extent combined therapy is more effective than traditional RIT. The only study comparing a combined therapy of thermal ablation and RIT versus traditional RIT monotherapy in a head to head study was carried out by Chianelli et al. [5], and found faster volume reduction and symptom relief and faster control of hyperthyroidism utilizing the combined therapy. In order to underline and verify the efficacy of the combined therapy, additional studies with more patients and extended follow-up periods are required. Thyroid function and volume development must be observed continuously.

\section{Conclusion}

\section{$\nabla$}

The 3-month follow-up study shows that the combined therapy of MWA and RIT displays an effective approach for the treatment of large benign nodular goiters. Very large goiters that had to be operated according to the German nuclear medicine guidelines could be treated conservatively and safely. A major benefit compared to surgery is the improvement or preservation of thyroid function accompanied by statistically significant thyroid volume reduction. Thyroid hormone substitution would not be required. Nevertheless, due to the limited number of patients, future studies with a stronger data base will have to investigate the longterm benefits.

\section{Clinical relevance of the study}

- The combination of MWA with RIT significantly reduces goiter volume, administered activity and hospitalization time.

- Thyroid function is preserved at the 3-month follow-up.

- Combined therapy can be seen as an innovative and conservative approach to treating very large benign nodular goiters.

\section{References}

1 Feng $B$, Liang $P$, Cheng $Z$ et al. Ultrasound-guided percutaneous microwave ablation of benign thyroid nodules: experimental and clinical studies. Eur J Endocrinol 2012; 166: 1031 - 1037

2 Gharib H, Papini E, Paschke R et al. American Association of Clinical Endocrinologists, Associazione Medici Endocrinologi, and EuropeanThyroid Association Medical Guidelines for Clinical Practice for the Diagnosis and Management of Thyroid Nodules. Endocr Pract 16: 1-43

3 Hegedüs L. Clinical practice. The thyroid nodule. N Engl J Med 2004; 351: $1764-1771$

4 Weetman AP. Radioiodine treatment for benign thyroid diseases. Clin Endocrinol (Oxf) 2007; 66: 757 -764

5 Chianelli M, Bizzarri G, Todino $V$ et al. Laser ablation and 131-iodine: A 24-month pilot study of combined treatment for large toxic nodular goiter. J Clin Endocrinol Metab 2014; 99: 1-5

6 Paschke R, Hegedüs L, Alexander E et al. Thyroid nodule guidelines: agreement, disagreement and need for future research. Nat Rev Endocrinol 2011; 7: $354-361$
7 Spiezia S, Garberoglio R, Milone F et al. Thyroid nodules and related symptoms are stably controlled two years after radiofrequency thermal ablation. Thyroid 2009; 19: 219-225

8 Korkusuz H, Fehre N, Sennert M et al. Early assessment of high-intensity focused ultrasound treatment of benign thyroid nodules by scintigraphic means. J Ther Ultrasound 2014; $2: 18$

9 Brace CL. Radiofrequency and microwave ablation of the liver, lung, kidney, and bone: what are the differences? Curr Probl Diagn Radiol 38: $135-143$

10 Korkusuz H, Happel C, Heck K et al. Percutaneous thermal microwave ablation of thyroid nodules. Preparation, feasibility, efficiency. Nuklearmedizin 2014; 53: $123-130$

11 Yue W, Wang S, Wang B et al. Ultrasound guided percutaneous microwave ablation of benign thyroid nodules: safety and imaging follow-up in 222 patients. Eur J Radiol 2013; 82: e11 - e16

12 Simon CJ, Dupuy DE, Mayo-Smith WW. Microwave ablation: principles and applications. Radiographics 2005; 25: S69-S83

13 Yang $Y$, Chen C, Zhang X. Microwave ablation of benign thyroid nodules. Futur Oncol 2014; 10: 1007-1014

$14 \mathrm{Yu}$ J, Liang $P$, Yu X et al. A comparison of microwave ablation and bipolar radiofrequency ablation both with an internally cooled probe: results in ex vivo and in vivo porcine livers. Eur J Radiol 2011; 79: 124 130

15 Marinelli LD, Quimby EH, Hine GJ. Dosage determination with radioactive isotopes; practical considerations in therapy and protection. Am J Roentgenol Radium Ther 1948; 59: 260-281

16 Happel C, Korkusuz H, Koch DA et al. Combination of ultrasound guided percutaneous microwave ablation and radioiodine therapy in benign thyroid diseases. A suitable method to reduce the 131I activity and hospitalization time? Nuklearmedizin 2015; 54

17 Dietlein $M$, Dressler J, Eschner $W$ et al. Procedure guideline for radioiodine test (Version 3). Nuklearmedizin 2007; 46: 198-202

18 Christou N, Mathonnet M. Complications after total thyroidectomy. J Visc Surg 2013; 150: 249-256

19 Baek JH, Lee JH, Valcavi R et al. Thermal ablation for benign thyroid nodules: radiofrequency and laser. Korean J Radiol 12: 525-540

20 Amabile G, Rotondi M, Pirali B et al. Interstitial laser photocoagulation for benign thyroid nodules: time to treat large nodules. Lasers Surg Med 2011; 43: 797-803

$21 \mathrm{Kim}$ YJ, Baek JH, Ha EJ et al. Cystic versus predominantly cystic thyroid nodules: efficacy of ethanol ablation and analysis of related factors. Eur Radiol 2012; 22: 1573-1578

22 Korkusuz H, Sennert M, Fehre $N$ et al. Local thyroid tissue ablation by high-intensity focused ultrasound: effects on thyroid function and first human feasibility study with hot and cold thyroid nodules. Int J Hyperthermia 2014; 30: 480-485

23 Korkusuz H, Nimsdorf F, Happel C et al. Percutaneous microwave ablation of benign thyroid nodules. Functional imaging in comparison to nodular volume reduction at a 3-month follow-up. Nuklearmedizin 2015; $54: 13-19$

24 Rotondi M, Amabile G, Leporati P et al. Repeated laser thermal ablation of a large functioning thyroid nodule restores euthyroidism and ameliorates constrictive symptoms. J Clin Endocrinol Metab 2009; 94: $382-383$

25 Spiezia S, Vitale G, Di Somma C et al. Ultrasound-guided laser thermal ablation in the treatment of autonomous hyperfunctioning thyroid nodules and compressive nontoxic nodular goiter. Thyroid 2003; 13 : $941-947$

26 Gharib H, Papini E, Paschke R et al. American Association of Clinical Endocrinologists, Associazione Medici Endocrinologi, and European Thyroid Association Medical guidelines for clinical practice for the diagnosis and management of thyroid nodules: executive summary of recommendations. Endocr Pract 16: $468-475$

27 Dottorini ME, Inglese E et al. Linee Guida. SIE-AIMN-AIFM per il Trat tamento Radiometa- bolico dell'Ipertiroidismo. book: vol. 00. 2009

28 Zingrillo $M$, Modoni S, Conte $M$ et al. Percutaneous ethanol injection plus radioiodine versus radioiodine alone in the treatment of large toxic thyroid nodules. J Nucl Med 2003; 44: 207 -210

29 Guglielmi R, Pacella CM, Bianchini A et al. Percutaneous ethanol injection treatment in benign thyroid lesions: role and efficacy. Thyroid 2004; $14: 125-131$

30 Gharib H, Hegedüs L, Pacella CM et al. Clinical review: Nonsurgical, image-guided, minimally invasive therapy for thyroid nodules. J Clin Endocrinol Metab 2013; 98: 3949-3457 
31 Happel C, Korkusuz H, Kranert WT et al. Combination of ultrasound guided percutaneous microwave ablation and radioiodine therapy for treatment of hyper- and hypofunctioning thyroid nodules. Nuklearmedizin 2014; 53: N48-N49

32 Jeong WK, BaekJH, Rhim H et al. Radiofrequency ablation of benign thyroid nodules: safety and imaging follow-up in 236 patients. Eur Radiol 2008; 18: $1244-1250$

33 Monzani F, Caraccio N, Goletti $O$ et al. Five-year follow-up of percutaneous ethanol injection for the treatment of hyperfunctioning thyroid nodules: a study of 117 patients. Clin Endocrinol (Oxf) 1997; 46: 9-15

34 Baek JH, Lee JH, Sung JY et al. Complications encountered in the treatment of benign thyroid nodules with US-guided radiofrequency ablation: a multicenter study. Radiology 2012; 262: 335-342

35 Rokni H, Sadeghi R, Moossavi Z et al. Efficacy of different protocols of radioiodine therapy for treatment of toxic nodular goiter: systematic review and meta-analysis of the literature. Int J Endocrinol Metab 2014; 12: e14424

36 Heck K, Happel C, Grünwald F et al. Percutaneous microwave ablation of thyroid nodules: effects on thyroid function and antibodies. Int J Hyperth 2015; 6736: 1-8

37 Valcavi R, Riganti F, Bertani A et al. Percutaneous laser ablation of cold benign thyroid nodules: a 3-year follow-up study in 122 patients. Thyroid 2010; 20: $1253-1261$

38 Nygaard B, Faber J, Veje A et al. Transition of nodular toxic goiter to autoimmune hyperthyroidism triggered by 131 I therapy. Thyroid 1999; 9: $477-481$

39 Dunkelmann $S$, Wolf $R$, Koch $A$ et al. Incidence of radiation-induced Graves' disease in patients treated with radioiodine for thyroid autonomy before and after introduction of a high-sensitivity TSH receptor antibody assay. Eur J Nucl Med Mol Imaging 2004; 31: 1428 - 1434 